\title{
THE WATER AND BASE BALANCE OF THE BODY 1
}

\author{
By PAUL H. LAVIETES, LOUIS M. D'ESOPO AND HAROLD E. HARRISON \\ (From The Department of Internal Medicine, Yale University, and The Medical Service of \\ the New Haven Hospital, New Haven)
}

(Received for publication November 1, 1934)

\section{INTRODUCTION}

A satisfactory method for the quantitative estimation of changes of hydration of the body is not available. Measurement of obvious fluids of the intake and output is of limited value. The method of determination of total water exchange proposed by Newburgh (1) has proved unsatisfactory in our experience (2). An approach to the problem through study of the electrolyte metabolism has the advantage that it gives information not only concerning the exchange of fluids between body and environment but also concerning the distribution of these fluids within the body.

That base (excluding calcium) and water are lost by the body in approximately the proportions in which they appear in the plasma was demonstrated by Gamble, Ross and Tisdall (3) from studies of fasting epileptic children. They suggested the use of this relationship for the estimation of water exchange from determined balances of cations. This procedure presupposes that total base is distributed evenly throughout the entire volume of body fluids and that the concentration of total base in these fluids remains constant while the volume of fluids changes. This need not be true, of course, for individual cations. Gamble's concept has gained wide acceptance and has served to add much to our knowledge of the interrelationship of the metabolism of base and of water.

The application of improved analytical methods to the determination of serum base has demonstrated that variations of one or two per cent are common, and that much wider variations occur under unusual circumstances. Comparisons by direct analyses of tissues (4), transudates (5, 6, $7,8)$, and red blood corpuscles $(9,10,11)$ with serum have shown, as might be inferred from the results of Gamble's experiments, that concentrations of total base per unit of water are approximately alike in all these media. The concentration

\footnotetext{
1 Part of the expense of this investigation was defrayed by a grant from the Ella Sachs Plotz Fund.
}

of base in the water of serum differs, however, slightly, but definitely, from that in the water of transudates or of red blood cells. Its relation to the concentration in other divisions of the body water has not been determined with sufficient accuracy to permit discussion. Whatever this may be, there is considerable evidence that a change of the concentration of base in any portion of the body water elicits changes of like direction and degree in all other portions. Klinghoffer (12) has shown that when water is added to human blood in vitro, the added water is redistributed almost immediately in such a manner that cell and serum water are increased nearly proportionally. Since it has been shown previously that under these conditions no base traverses the cell membrane $(13,14)$, the inference that the base of cellular water falls nearly in direct proportion to that of the serum seems warranted. In similar experiments in which salts of sodium and potassium were added to blood, sufficient water was transferred from the cells to the serum to keep the concentration of total base per unit of water in cells and sęrum approximately equal (14). When urea or glucose solutions were added to blood, the water of cells and of serum increased nearly proportionally, the added solutes distributing themselves evenly throughout all the water present, without any exchange of base between cells and serum (12). When hypertonic solutions of sucrose, to which the cell membranes are impermeable, were added, on the contrary, water was drawn from the cells, and the concentration of base in the water of the cells rose above that in the water of the serum (12). These findings are in accord with the theory of osmotic pressure which demands that only those solutes to which the cell membrane is impermeable exert an osmotic influence upon the distribution of water between cells and serum. In the body the total electrolyte concentrations can be measured by the concentrations of the inorganic bases which are apparently unable to traverse cellular membranes 
and make up the major portion of the osmotically effective substance of the fluid media. Changes in the concentration of base in any portion of the body water should, then, be compensated by like changes in the other portions, if osmotic equilibrium is to be maintained. In several experiments after large changes in the concentration of base in the serum of man in vivo, the volume of water in the cells has changed proportionally in the opposite direction (15), conforming to the results of the in vitro experiments cited above. There is no direct evidence that the concentration of base in the water of tissues other than the red blood cells varies directly with that of serum, but from theoretical considerations one would expect this to be true if the isotonicity of the body fluids is to be maintained, unless non-electrolytes to which the membranes are not permeable are quantitatively significant or unless there is change of $\mathrm{pH}$ and hence of base bound by protein. Schechter (16) and Schechter, Cary, Carpentieri and Darrow (17) have found that, following the intraperitoneal injection of various fluids in dogs, there is a fairly rapid redistribution of water and electrolytes so that the peritoneal fluid approaches the relationship to serum which is ordinarily found to exist between transudates and serum. In similar experiments, Yannet and Darrow (11) found that measures which changed the concentration of base in the serum caused inverse variations in the size of the red blood corpuscles. Direct analyses of whole blood and serum in these experiments showed that, with few exceptions, the actual amount of base in the cells remained unchanged, but that the changes of volume were sufficient to equalize the concentrations of base in the water of cells and serum.

If it is true that changes of the concentration of base are distributed over a large volume of fluid, even slight changes in concentration may be quite significant in attempts to relate balances of water and base. For example, in a subject weighing $50 \mathrm{kgm}$., of which about $35 \mathrm{kgm}$. is water, a change of two milliequivalents in the concentration of base would allow the gain or loss of 35 $\times 2=70 \mathrm{~m}$. Eq. of base without change in the volume of fluid in the body. Conversely, a change of $2 \mathrm{~m}$. Eq. in the concentration of base, if this were originally $150 \mathrm{~m}$. Eq. per liter, would be produced by a change in the volume of body fluids of $35 \times \frac{2}{150}=0.467$ liters without either gain or loss of base by the body. Such phenomena may explain the apparent lack of correlation between balances of water and base which have been observed occasionally in this laboratory and elsewhere. Even small changes of concentration cannot be dismissed from consideration in such studies, as has frequently been done, merely because methods adequate to measure such variations have not been available.

\section{Total water exchange}

If base does tend to distribute itself throughout the fluid media of the body in definite and relatively constant proportion to water, it should be possible to estimate body water exchange from the balances and changes of concentration of base in serum by the following formula:

$$
\mathrm{W}_{1} \mathrm{~B}_{1}+b=\mathrm{W}_{2} \mathrm{~B}_{2} \text {. }
$$

in which $W_{1}$ and $W_{2}$ represent the volume of water in the body at the start and at the conclusion of the period of study, respectively; $B_{1}$ and $B_{2}$, the corresponding concentrations of $\mathrm{Na}+\mathrm{K}$ in the water of serum; and $b$, the net gain or loss of $\mathrm{Na}+\mathrm{K}$ by the body. This equation may be written

$$
\mathrm{W}_{1} \mathrm{~B}_{1}+b=\mathrm{B}_{2}\left(\mathrm{~W}_{1}+\Delta \mathrm{W}\right),
$$

in which $\Delta \mathrm{W}=\mathrm{W}_{2}-\mathrm{W}_{1}$, or water exchange. Solved for $\Delta W$, this becomes

$$
\Delta \mathrm{W}=\frac{b+\mathrm{W}_{1} \Delta \mathrm{B}}{\mathrm{B}_{2}},
$$

in which $\Delta B=B_{1}-B_{2}$, the change of the concentration of base in the water of the serum. If the concentration of base does not change, the equation is simplified to:

$$
\Delta \mathrm{W}=\frac{b}{\mathrm{~B}},
$$

which represents essentially Gamble's method of calculation. $\mathrm{Na}+\mathrm{K}$ has been used rather than total base because the other bases, calcium and magnesium, are found in the water of the body in relatively small amounts and exert an osmotic effect that is small as compared with their acidcombining power because they are bivalent and partly in undissociated combinations with protein. 
This is certainly true of serum, transudates and red blood corpuscles. Tissue cells, however, contain a considerable amount of magnesium, neglect of which may conceivably introduce error into calculations. In prolonged fasting $(3,18)$ the ratio $\frac{\mathrm{Mg}}{\mathrm{K}+\mathrm{Mg}}$ in the excreta, expressed in millimols, is almost identical with that in muscle, 0.097 (4). It is, therefore, possible that ten per cent of the osmotic effect of the base of cells is contributed by magnesium. In the one experiment here reported in which magnesium balances were determined the largest change noted was a retention of 12 millimols in a four-day period.

Equation 2 can be solved for total water exchange providing a value for the initial volume of fluid, $\mathrm{W}_{1}$, can be found. It has been customary in metabolic work to assume that approximately 70 per cent of the weight of the body is water. The water content of normal rats, rabbits and dogs has been found by direct analysis to approximate this value $(19,20)$. Measurements of osmotic changes in the serum following the injection of hypertonic salt solutions by Hetherington (21) indicated that on the average 59 per cent of the body weight of cats was composed of water which was available as solvent. It should be possible, in short studies on subjects in whom large changes of body water and base are induced by various measures, to determine the initial volume of fluids from Equation 2 by assuming that observed changes of body weight represent water exchange. This unfortunately has not proved of value because the changes in concentration must be extremely large to overbalance analytical errors. In a single experiment with forced urea feeding, the urea was found to distribute itself through approximately 70 per cent of the body weight of a normal subject (22). In the calculation of water exchange by Equation 2, the initial water content of the body will be taken to be 70 per cent of the initial body weight, with the understanding that this is merely an approximation, serving to correct only roughly for changes in the concentration of base in the water of the body.

\section{Changes in the volume of extracellular fluids}

There is much evidence to support the view that almost all of the sodium of the body is confined to the extracellular fluids, and that the same is true of chloride, if the red blood corpuscles are excluded from consideration. This evidence has been summarized briefly by Peters (23). If this be true, extracellular water exchange $(\Delta \mathrm{E})$ may be calculated from sodium metabolism as follows:

$$
\mathrm{Na}_{1} \mathrm{E}_{1}+b_{\mathrm{Na}}=\mathrm{Na}_{2} \mathrm{E}_{2} \text {, }
$$

where $\mathrm{Na}_{1}$ and $\mathrm{Na}_{2}$ represent the average concentrations of $\mathrm{Na}$ in extracellular water at the beginning and at the end of the period of study; $E_{1}$ and $E_{2}$ represent the volume of extracellular fluids at corresponding times; and $b_{\mathrm{Na}}$ represents the $\mathrm{Na}$ balance. By substituting $\mathrm{E}_{1}+\Delta \mathrm{E}$ for $E_{2}$ in the above equation, it may be solved for $\Delta \mathrm{E}$.

$$
\Delta \mathrm{E}=\frac{b_{\mathrm{Na}}+\mathrm{E}_{1}(\Delta \mathrm{Na})}{\mathrm{Na}_{2}} .
$$

Likewise if the $\mathrm{Cl}$ of the red blood corpuscles is neglected, ${ }^{2}$

$$
\Delta \mathrm{E}=\frac{b_{\mathrm{Cl}}+\mathrm{E}_{1}(\Delta \mathrm{Cl})}{\mathrm{Cl}_{2}} .
$$

While it is known that the concentration of $\mathrm{Na}$ in the water of transudates is slightly lower than that of serum water and that of $\mathrm{Cl}$ slightly higher $(5,6,7,8)$, changes in the concentration of either $\mathrm{Na}$ or $\mathrm{Cl}$ of serum are reflected in similar changes in their concentrations in transudates. Little error will therefore be introduced into the calculations if, for the average concentrations of $\mathrm{Na}$ and $\mathrm{Cl}$ in extracellular water, their respective concentrations in serum water are used. A single unknown, $E_{1}$, remains.

Theoretically if Equations 4 and 5 are both accurate expressions of extracellular water exchange, it should be possible, by equating the two, to solve for the initial volume of these fluids.

2 If 7 per cent of the body weight is assumed to be blood, with a cell volume of 40 per cent and cell water of 70 per cent, the water of the red blood corpuscles becomes $7 \times 0.4 \times 0.7=2$ per cent of the body weight. The concentration of chloride in this water is considerably lower than that in the serum water (approximately $75 / 110$ ), and if other factors remain constant, changes of concentration occur in the same ratio. On the basis of the above values, the red blood cells of a $50 \mathrm{kgm}$. man contain only about $75 \mathrm{~m}$. Eq. of $\mathrm{Cl}$, an insignificant amount in comparison with the $\mathrm{Cl}$ of the interstitial fluids. 
Practically this procedure has been impossible because errors well within the limits of analytical accuracy may prove of overwhelming significance. It is possible that in experiments specially planned to produce large discordant changes in the concentrations of $\mathrm{Na}$ and $\mathrm{Cl}$ this method may yet prove feasible. From the values for base in muscle, obtained by Katz (4), by assuming that all the $\mathrm{Na}$ is contributed by interstitial fluid, it has been calculated that extracellular water made up 20 per cent of the muscle weight (23). These figures are corroborated by recent analyses of dog muscle made by Hastings (24). Eggleton (25, 26) has shown that certain solutes diffuse through all the water of the frog muscle, while other substances diffuse through only 20 to 30 per cent of the water of vital frog muscle, presumably the extracellular portion. After rigor mortis has set in this selective permeability disappears. Crandall and Anderson (27) have found that after the intravenous injection of $\mathrm{NaCNS}$, the CNS radical distributes itself through approximately 24 per cent of the body weight of normal man. These authors suggest this procedure as a measure of the "state of hydration" of the body. In tissues, analyses revealed little enough CNS to be attributed solely to the interstitial fluid included with the cellular substance. It seems probable, then, that this procedure measures roughly the volume of the interstitial fluids plus the water of the red blood corpuscles. If this is true, the extracellular fluid volume in their series would be about 22 per cent of the body weight. The salt was found to enter the gastro-intestinal secretions so that if any appreciable amount of these secretions were formed during the experiments, the true value for the volume of extracellular fluid would be even lower than this. Preliminary studies of the distribution of intravenously injected sucrose in man conducted in this Department indicate that the volume of the interstitial fluids normally approximates 20 per cent of the body weight. It seems justifiable, on the basis of the foregoing evidence, to use as a rough approximation of extracellular fluid volume in Equations 4 and 5, 20 per cent of the body weight. The results of the calculations are but little altered if 15 or 25 per cent is used instead.

The data from 10 experiments conducted in this Department are available for evaluation of the formulae described for the study of water exchanges. These data are suitable for this purpose because they satisfy the following criteria (except in the last two experiments which will be discussed separately):

1. The body tissues presumably changed little because the food taken approximated the energy requirements.

2. Water exchanges were sufficiently large to permit the assumption that, within the requisite limits of error, water exchange was equal to the change of body weight.

3. Digestive disturbances were absent. Diets were completely taken except in Experiments 7 and 8 in which a little food was refused. No food or fluids had been taken for at least 8 hours before the start or end of an experiment.

4. There was no evidence of sensible perspiration.

\section{EXPERIMENTAL PROCEDURE}

No food, drink or medication was given for at least 8 hours, and usually 12 hours, before a period of study was started or concluded, except in the subjects with uncontrolled diabetes insipidus in whom water was withheld for a shorter period. The subject was weighed at the beginning and at the end of each period of study. A silk balance capable of weighing \pm 5 grams was used. Blood for analysis was drawn before the first and after the second weighing in experiments consisting of only one period. When an experiment comprised more than one period, blood drawn was included in the output for the period in which it was drawn in the calculation of balances and insensible perspiration. Urine voided just before the first weighing was discarded; all the subsequent voidings, including one just prior to the second weighing, were combined for analysis. Carmine capsules were used to separate the stools. Salt-poor mixed diets were prepared in the diet-kitchen except in Experiment 5, in which the diet consisted only of weighed portions of milk, cream, shredded wheat, sugar and salt. In Experiments 6 and 8 , the diets used in each period were identical in all respects, thus decreasing the possibility of error through variability of diets.

In experiments on diseased subjects, detailed supervision was required to insure the collection of all excreta and the accurate measurement of all ingesta. No pains were spared to gain the cooperation of patients, nurses and orderlies. Water was supplied from the laboratory in weighed thermos bottles. The subjects' tastes were consulted before preparing the diet in order to lessen the probability of refusals. Corrections for the small amounts of food refused by the subject of Experiment 8 were made by the use of the tables of Sherman (28). In Experiment 7, food equal to that refused was removed 
from the duplicate diet before it was prepared for analysis. The vomitus present in Experiment 10 was analyzed for electrolytes. Parenteral fluids, used only in Experiments 9 and 10, were weighed, and portions saved for analysis. Urine was collected at the bedside in a three liter bottle containing a crystal of thymol and about one gram of solid benzoic acid. Stools were immediately sent in the bed pans to the laboratory refrigerator. All stools were weighed, but those preceding the appearance of the carmine were not saved for analysis. About 100 grams of water and about 2 grams of benzoic acid were added as preservatives to the stools after they had been weighed. The mixture was kept in the refrigerator.

Anaerobic precautions were observed in collecting blood for analysis. Serum was obtained from blood clotted under oil. Protein was determined by the macroKjeldahl method with the aid of superoxol in the digestion; chloride by the method of Van Slyke as modified by Eisenman (29); sodium and potassium by the methods of Barber and Kolthoff (30) and Shohl and Bennett (31) respectively, with the modifications described by Hald (32); total base by a modification of the method of Stadie and Ross (33), with titration of the precipitate, except in Experiment 8 when the gravimetric procedure of Hald (32) was employed. In the shorter experiments, the sera were analyzed together at the end of the experiment, thus eliminating the effect of variable blanks and reagents on the comparability of the analytical values.

Urine $\mathrm{N}$ was determined by the macro-Kjeldahl method; urine $\mathrm{Cl}$ by the Harvey modification (34) of the Volhard method; $\mathrm{Na}$ and $\mathrm{K}$ by methods similar to those used for serum (to be published). A generous portion of the urine, including some of the solid benzoic acid contained in it, was saved in a glass-stoppered bottle in the refrigerator to provide for repetition of analyses if these proved necessary. Urine so preserved was found to have an acid reaction and an unchanged chloride concentration after one month.

The stools from each period were transferred with the aid of water to a weighed wide-mouthed three liter bottle, mixed for an hour with a mechanical stirrer, weighed, and a portion saved for analysis. Weighed aliquots were analyzed for $\mathrm{Cl}$ by the method used for serum; $\mathrm{Na}$ and $\mathrm{K}$ by the methods described for urine; and $\mathrm{N}$ by the Kjeldahl method with the aid of superoxol in the digestion. In the later experiments wherever $\mathrm{K}$ was present in excess of $\mathrm{Na}$, as was the case in all of the diets, most of the stools and some of the urine specimens, $\mathrm{Na}$ was determined after $\mathrm{K}$ had been removed with chloroplatinate as described by Hald (32).

Duplicate diets prepared in the diet kitchen were weighed. The fluid portions were transferred to a widemouthed 3 liter bottle. The remainder, after it had been passed through a meat-grinder, was added to the fluids. The whole was mixed with a mechanical stirrer for an hour, and a portion, to which about 1 gram of benzoic acid was added, was saved for analysis. Weighed aliquots were analyzed by the methods described for stools, it being assumed that the aliquots so obtained were repre- sentative of the entire original weight of the diet, this weight being therefore used in the calculations. On one occasion, when the diet was reweighed in the mixing bottle at the end of the procedure, it was found to have lost exactly one per cent of its original weight. The effect of this loss is insignificant, particularly since it probably has approximately the same composition as the whole. An alternative method of preparation, in which the containers and grinder were washed quantitatively with water and the entire mixture weighed before aliquots were taken, gave almost identical results in the one instance in which the comparison was made. The uniformity of the food mixture has been repeatedly ascertained by analyses of aliquots taken from the top and bottom of the mixture. Nitrogen analyses on diets so prepared usually give results 5 to 10 per cent higher than the values predicted from the diet tables. This may be due to the fact that nitrogen may be lost by volatilization if materials are dried preparatory to analysis, the procedure employed for most of the analyses from which the tables were compiled. The essential correctness of our analytical values for $\mathrm{N}$ of food is confirmed by the exact balances which have been obtained in prolonged studies of normal individuals with constant adequate intakes. The diets usually used in these experiments contained of the order of $60 \mathrm{~m}$. Eq. of Cl, $50 \mathrm{~m}$. Eq. of $\mathrm{Na}$ and $100 \mathrm{~m}$. Eq. of $\mathrm{K}$ daily. The constantly noted excess of $\mathrm{Cl}$ over $\mathrm{Na}$ gave rise to some misgivings. The results of $\mathrm{Cl}$ analyses by the method of Sunderman and Williams (35), however, agreed with those obtained by our method, and the values for sodium plus potassium determined separately checked satisfactorily with those secured by their determination as combined sulfates. It was found that analyses for $\mathrm{Na}$ and $\mathrm{K}$ in excreta and ingesta yielded more consistent and generally higher results when small aliquots (about 5 grams) were ashed than when larger aliquots were used. Because of the difficulty of completely ashing the larger aliquots employed earlier ( 20 to 40 grams), these ions were probably lost by volatilization or incompletely recovered. By using small aliquots and observing all the precautions described by Hald, it is felt that accuracy within $\pm 3 \mathrm{~m}$. Eq. daily may be attained in the determination of either $\mathrm{Na}$ or $\mathrm{K}$ of the urine or food, although a greater error undoubtedly was present in the earlier experiments when the methods were as yet poorly developed. It has been possible to reproduce diets which vary only slightly in the amounts of $\mathrm{Na}$ and $\mathrm{K}$ which they contain.

\section{EXPERIMENTAL SUBJECTS AND TREATMENT OF} EXPERIMENTAL RESULTS

The subject of Experiment 1 was a male with hypertension who, during the experimental period of 8 days, gained 490 grams in weight spontaneously. The subjects of Experiments 2 and 3 presented the nephrotic syndrome. The former had a spontaneous diuresis during the experimental 
period of 4 days. In the latter water storage was induced by the administration of sodium chloride. The subject of Experiments 4 and 5 was a normal male. In the first experiment a slight water loss was induced by the administration of 40 grams of urea daily. In the second, marked dehydration was produced by the administration of 180 grams of urea with limited fluid intake during the first 24-hour period, and rehydration was partially accomplished during the second period by the administration of added water and salt. The subjects of Experiments 6 and 7 were patients with diabetes insipidus who were allowed water ad libitum. In Experiment $6,^{3}$ the same low-salt diet was given in each period. During the first period, 0.5 cc. of pituitrin was given three times daily; during the second no pituitrin was given. In Experiment 7 the diet was approximately the same each day except that added salt was given during the last 2 periods. One cc. of pituitrin was given four times daily during Periods 2 and 5 . The subject of Experiment 8 had rheumatic heart disease with moderate cardiac decompensation and rheumatic nephritis with marked renal insufficiency. Large amounts of water were administered in both periods. The food was identical during the 2 periods, but 35.5 grams of $\mathrm{NaCl}$ were given in addition to the diet during the second period.

Results with the method of Newburgh and Johnston for the determination of water exchange of the body, which, it had been hoped, would serve as a check upon these calculations, proved disappointing (2). Under the conditions of the present experiments, in which diets approximate energy requirements and in most cases were taken for many days preceding the experiments, little error can be introduced by assuming that observed changes of body weight represent exchanges of fluid only. Where the periods are short and the weight changes large this is especially true. In Experiments 9 and 10, a more difficult situation exists. In the former, a girl of 17 years, with vomiting probably of neurotic origin, had retained very little food for a week prior to the experiment. During the 40 hour experiment nothing

\footnotetext{
8 For the opportunity to study this patient the authors are indebted to Dr. Daniel C. Darrow, Assistant Professor of Pediatrics.
}

was given by mouth and no nausea or vomiting occurred. The food intake was restricted to 90 grams of glucose and 33.3 grams of $\mathrm{NaCl}$ given parenterally. The patient was extremely cooperative and quiet. Because of the previous starved condition the metabolism must have been low and the glycogen stores probably suffered little or no further depletion during the experiment. The urinary $\mathrm{N}$ indicated a protein metabolism of 60 grams. The energy requirement of this small inactive subject would probably be more than covered by the additional loss of 200 grams of fat. The error incurred by the assumption that water exchange equals the body weight change plus about 260 grams to replace the tissue losses must be very slight. The subject of Experiment 10, a patient with anuria resulting from a suicidal attempt with mercuric chloride, was given only saline and glucose solutions parenterally and water and sodium bicarbonate by mouth. During the second day of the experiment he felt somewhat nauseated and vomited once following the ingestion of water, but during the remainder of the experiment, suffered no discomfort. During the $3 \mathrm{~d}$ and 4th days urine secretion was reestablished. The insensible perspiration, which varied widely from day to day, averaged 1504 grams per day. If the normal relationship between insensible loss and metabolism is assumed to exist, this would indicate a metabolism of over 3300 calories per day. A considerable depletion of glycogen must have occurred during this period of virtual starvation. At any rate it is reasonable to assume that a loss of over one kilogram, and not more than two kilograms of body tissue must have occurred during this 4 day experiment so that water gained must have exceeded the weight gained by that amount.

\section{PRESENTATION OF RESULTS}

The essential data are presented in Table I. The concentrations of $\mathrm{Na}, \mathrm{Cl}$ and protein in the serum are given in all cases; those of $\mathrm{K}$ and total base whenever they are available. The reliability of the base values in the first 4 experiments must be questioned on the basis of internal evidence and errors of chemical analysis which were discovered later. The differences between $\mathrm{Na}$ and total base in the first and fourth experiments and in the fina! examinations in Experiments 2 and 3 are too 
TABLE I

Essential data

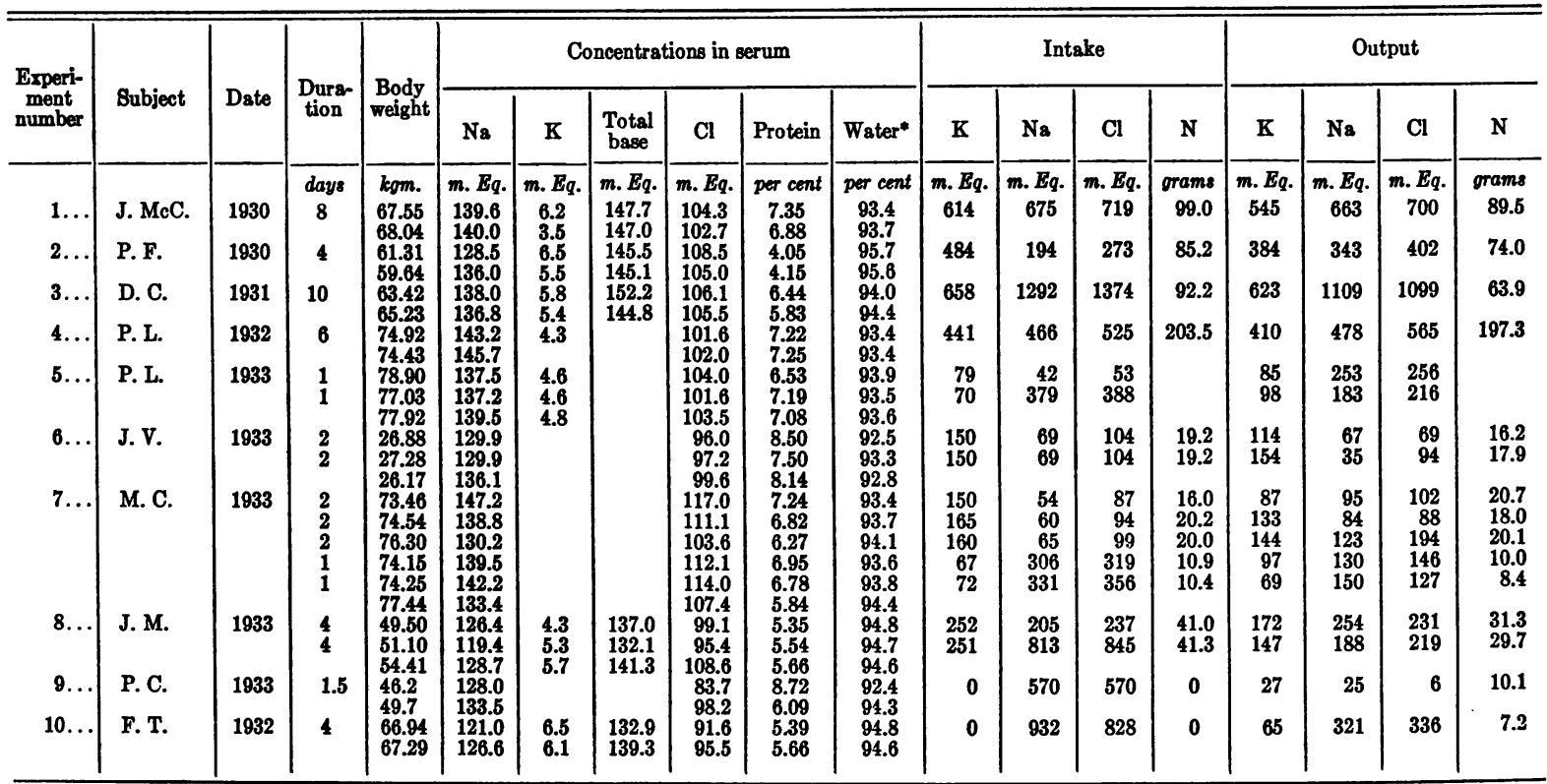

* Serum water was not determined but was calculated from serum protein by the formula 98.57-0.709 (Protein), derived statistically by Eisenman and Peters (44).

small to allow for the expected amounts of bases other than $\mathrm{Na}$. This is probably due to the fact that in precipitating the sodium salt in the early experiments as little water as possible was used in dissolving the ash instead of the fixed proportion of water to reagent recommended by Kolthoff, thus yielding results for $\mathrm{Na}$ which were too high. In Experiment 1 there must be an error in the $\mathrm{K}$ analyses since the wide variation is at odds with the constancy of $\mathrm{Na}$, total base, and $\mathrm{Cl}$. In Experiment 2, a large rise in $\mathrm{Na}$ occurs without any comparable rise in total base. In the third experiment, the observed decreases in $\mathrm{Na}$ and total base are disproportionate. In the remaining experiments, errors in the determinations of either $\mathrm{Na}$ or $\mathrm{Cl}$ greater than $1 \mathrm{~m}$. Eq. per liter are improbable. In all of these the sum of the determined concentrations of $\mathrm{Cl}, \mathrm{CO}_{2}$ and protein in the serum, expressed in terms of base-combining powers, were used to check the observed changes of concentration of base. In Experiments 7,8 and 9, osmotic pressure, determined by Dr. A. Gilman of the Department of Pharmacology, was found to vary proportionally to base. In Experiment 8 , the complete system of base analyses was performed. The results are presented in Table II.
TABLE II

Data on serum from Experiment 8

\begin{tabular}{|c|c|c|c|c|c|c|c|}
\hline Serum & $\mathrm{Na}$ & $\mathbf{K}$ & $\begin{array}{l}\mathrm{Na}+\mathrm{K} \\
\text { as } \mathrm{SO}_{4}\end{array}$ & $\mathrm{Ca}$ & $\mathbf{M g}$ & $\begin{array}{l}\text { Sum of } \\
\text { bases }\end{array}$ & $\begin{array}{c}\text { Total } \\
\text { base as } \\
\text { SO. }\end{array}$ \\
\hline $\begin{array}{l}1 \\
2 \\
3\end{array}$ & $\begin{array}{c}\text { m. Eq. } \\
126.4 \\
119.4 \\
128.7\end{array}$ & $\begin{array}{c}m . E q . \\
4.3 \\
5.3 \\
5.7\end{array}$ & $\begin{array}{l}\text { m. Eq. } \\
130.1 \\
123.5 \\
134.2\end{array}$ & $\begin{array}{c}\text { m. Eq. } \\
4.4 \\
3.7 \\
3.4\end{array}$ & $\begin{array}{c}\text { m. Eq. } \\
1.4 \\
1.8 \\
1.9\end{array}$ & $\begin{array}{l}\text { m. Eq. } \\
136.5 \\
130.2 \\
140.0\end{array}$ & $\begin{array}{c}\text { m. Eq. } \\
137.0 \\
132.0 \\
141.3\end{array}$ \\
\hline
\end{tabular}

The recorded outputs of electrolytes and $\mathrm{N}$ neglect any loss which may occur through the skin and lungs. Loss of $\mathrm{N}$ through these avenues is negligible even when moderate sweating occurs. That appreciable loss of electrolytes may occur through sweating is admitted. Sensible perspiration did not occur in any of these experiments, however. There is much evidence to show that under these conditions electrolyte loss through the skin is negligible. The chloride of urine and stool has been found to approximate very closely that of the intake in a prolonged study, on a normal subject who avoided sweating (36), thus making it improbable that the insensible perspiration contained appreciable amounts of $\mathrm{Cl}$. Hancock, Whitehouse and Haldane (37) were able to re- 
cover only 0.09 gram $\mathrm{Cl}$ and 0.08 gram $\mathrm{K}$ from the washings of the skin of a normal subject who had not bathed for one week, but who had not sweated sensibly nor been exposed to warm weather. From this, and from further experiments in which variable amounts of sweating were induced, these authors concluded that, when the loss of water through the skin is small, the water passes through the skin by osmosis without the intermediation of the sweat glands, and the small amount of electrolyte lost is derived from epidermis or from the sebacious secretions. Viale (38) could recover no appreciable amount of $\mathrm{Cl}$ from the skin of the arm at rest until the temperature was raised, thus presumably calling the sweat glands into play. Vasti (39) applied strips of smooth white paper to the washed skin of normal human subjects for a few minutes. He then dipped the paper in 10 per cent silver nitrate and exposed it to the sunlight. By this method the passage of even minute traces of $\mathrm{Cl}$ through the skin may be detected. Although loss of water from the skin area could be demonstrated in every case, punctate brown stains, presumably marking active sweat glands, were found in only 5 instances. In these the insensible perspiration was 18 to 72 per cent above the average. It seems reasonable to conclude that where the sweat glands are inactive, perspiration occurs only through evaporation of water from the superficial layers of the skin which is continuously renewed from below by the resulting osmotic gradient. This entails no loss of salt. Under the conditions of our experiments, the activity of the sweat glands must have been minimal and loss of electrolytes through the skin may be neglected.

In Table III the data are presented in a form which is more convenient for the calculation of water exchanges. The balances of $\mathrm{Na}+\mathrm{K}, \mathrm{Na}$ and $\mathrm{Cl}$ are recorded as $b, b_{\mathrm{Na}}$ and $b_{\mathrm{Cl}}$ respectively. The concentrations of electrolytes in the water of serum recorded to the nearest milliequivalent, are obtained by dividing the observed concentrations by the water content of the serum. Finally 70 per cent of the initial body weights are recorded as $\mathrm{W}_{1} ; 20$ per cent as $\mathrm{E}_{1}$. These approximations of the initial volumes of the total and the extracellular water of the body have been used in the calculations for reasons previously discussed.

In Table IV are presented the results of calculation of the water exchanges in these experiments by the formulae proposed above. Total water exchange $(\Delta W)$ is calculated from base metabolism with and without correction for changes of concentrations by Equations 2 and 3 respectively. The observed changes of body weight are also

TABLE III

Data presented for ease in calculation of water exchanges

\begin{tabular}{|c|c|c|c|c|c|c|c|c|c|c|c|c|c|c|c|}
\hline \multirow{2}{*}{$\begin{array}{l}\text { Experi- } \\
\text { ment }\end{array}$} & \multirow{2}{*}{ Subject } & \multicolumn{3}{|c|}{ Electrolyte balances } & \multicolumn{11}{|c|}{ Concentrations of electrolytes in serum water* } \\
\hline & & $b$ & $b_{\mathrm{Na}}$ & $b_{\mathbf{C l}}$ & $\mathbf{B}_{\mathbf{1}}$ & $\mathbf{B}_{\mathbf{2}}$ & $\Delta \mathbf{B}$ & $\mathrm{Na1}$ & $\mathrm{Na}$ & $\Delta \mathrm{Na}$ & $\mathrm{Cl}_{1}$ & $\mathrm{Cl}_{\mathbf{2}}$ & $\Delta \mathrm{Cl}$ & $\mathrm{W}_{\mathbf{1}}$ & $\mathbf{E}_{1}$ \\
\hline $\begin{array}{l}1 \ldots \\
2 \ldots \\
3 \ldots \\
4 \ldots \\
5 \ldots \\
6 \ldots \\
7 \ldots\end{array}$ & $\begin{array}{l}\text { J. McC. } \\
\text { P. F. } \\
\text { D. C. } \\
\text { P. L. } \\
\text { P. L. } \\
\text { J. V. } \\
\text { M. C. } \\
\text {. }\end{array}$ & $\begin{array}{r}\text { m. Eq. } \\
81 \\
-49 \\
218 \\
19 \\
-217 \\
168 \\
38 \\
30 \\
22 \\
8 \\
-42 \\
146 \\
184 \\
31 \\
729 \\
518 \\
546\end{array}$ & $\begin{array}{r}\text { m. Eq. } \\
12 \\
-149 \\
183 \\
-12 \\
-211 \\
196 \\
2 \\
34 \\
-41 \\
-24 \\
-58 \\
176 \\
181 \\
-49 \\
625 \\
545 \\
611\end{array}$ & $\begin{array}{r}m . E q . \\
19 \\
-129 \\
275 \\
-40 \\
-203 \\
172 \\
35 \\
10 \\
-15 \\
6 \\
-95 \\
173 \\
229 \\
6 \\
626 \\
564 \\
492\end{array}$ & $\begin{array}{c}\text { m. Eq. } \\
156 \\
141 \\
153 \\
158 \\
151 \\
152 \\
145 \\
144 \\
163 \\
153 \\
143 \\
154 \\
157 \\
138 \\
132 \\
139 \\
135\end{array}$ & $\begin{array}{c}\text { m. Eq. } \\
156 \\
148 \\
151 \\
161 \\
152 \\
154 \\
144 \\
152 \\
153 \\
143 \\
154 \\
157 \\
146 \\
132 \\
142 \\
142 \\
140\end{array}$ & $\begin{array}{r}m . E q . \\
0 \\
-7 \\
2 \\
-3 \\
-1 \\
-2 \\
1 \\
-8 \\
10 \\
10 \\
-11 \\
-3 \\
11 \\
6 \\
-10 \\
-3 \\
-5\end{array}$ & $\begin{array}{c}m . E q . \\
150 \\
134 \\
147 \\
153 \\
146 \\
147 \\
140 \\
139 \\
158 \\
148 \\
138 \\
149 \\
152 \\
133 \\
126 \\
139 \\
128\end{array}$ & $\begin{array}{c}m . E q . \\
150 \\
142 \\
145 \\
156 \\
147 \\
149 \\
139 \\
147 \\
148 \\
138 \\
149 \\
152 \\
141 \\
126 \\
136 \\
142 \\
134\end{array}$ & $\begin{array}{r}m . E q . \\
0 \\
-8 \\
2 \\
-3 \\
-1 \\
-2 \\
1 \\
-8 \\
10 \\
10 \\
-11 \\
-3 \\
11 \\
7 \\
-10 \\
-3 \\
-6\end{array}$ & \begin{tabular}{|c} 
m. Eq. \\
112 \\
113 \\
113 \\
109 \\
111 \\
109 \\
104 \\
104 \\
125 \\
119 \\
110 \\
120 \\
122 \\
105 \\
101 \\
91 \\
97
\end{tabular} & $\begin{array}{c}m . E q . \\
110 \\
110 \\
112 \\
109 \\
109 \\
111 \\
104 \\
107 \\
119 \\
110 \\
120 \\
122 \\
114 \\
101 \\
115 \\
104 \\
101\end{array}$ & \begin{tabular}{|r}
$m . E q$. \\
2 \\
3 \\
1 \\
0 \\
2 \\
-2 \\
0 \\
-3 \\
6 \\
9 \\
-10 \\
-2 \\
8 \\
4 \\
-14 \\
-13 \\
-4
\end{tabular} & $\begin{array}{c}\text { m. Eq. } \\
47 \\
43 \\
44 \\
52 \\
55 \\
54 \\
19 \\
19 \\
51 \\
52 \\
54 \\
52 \\
52 \\
35 \\
36 \\
32 \\
47\end{array}$ & $\begin{array}{r}m . E q . \\
14 \\
12 \\
13 \\
15 \\
16 \\
15 \\
5 \\
5 \\
15 \\
15 \\
16 \\
15 \\
15 \\
10 \\
10 \\
9 \\
13\end{array}$ \\
\hline
\end{tabular}

* The electrolyte concentrations in serum water are calculated by dividing determined serum electrolyte concentrations by serum water content, and recording the results to the nearest unit. A constant value has been assumed for serum potassium when it was not determined by analysis. 
TABLE IV

Water exchanges calculated by various methods

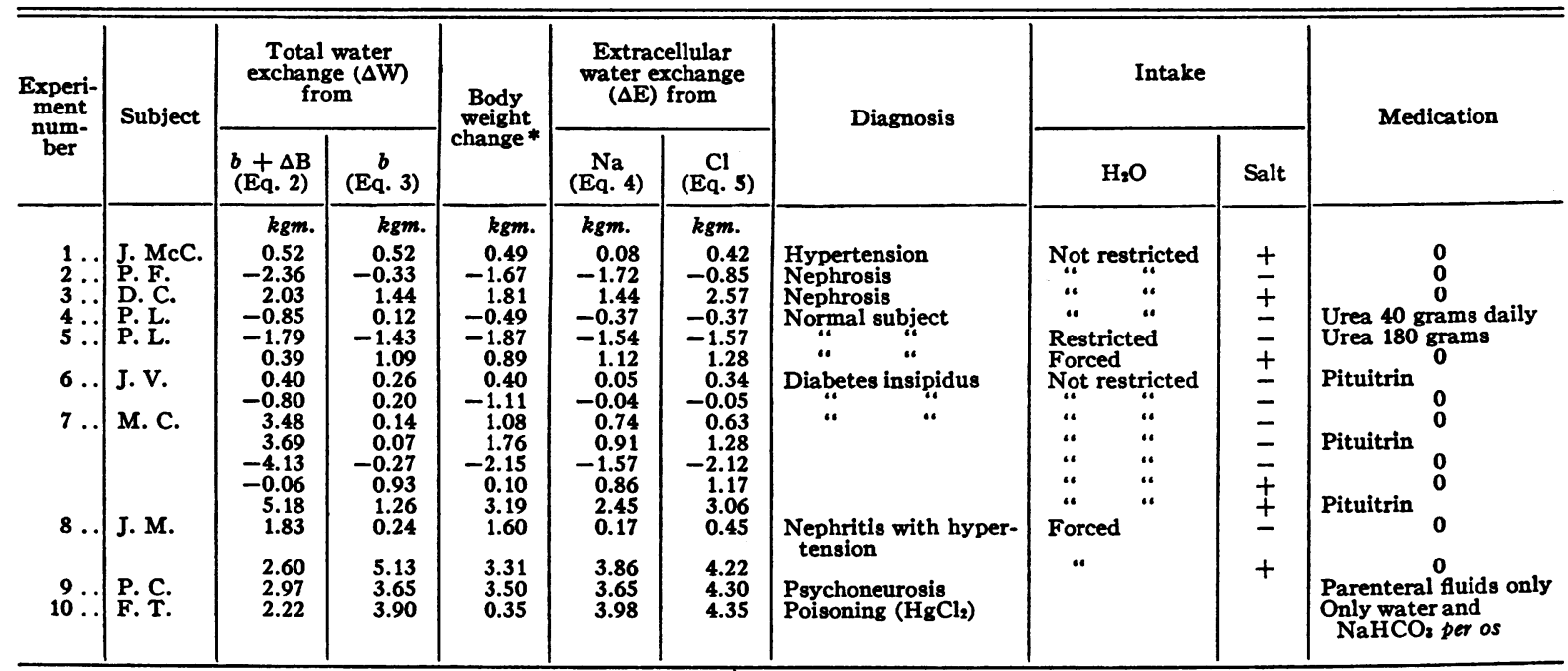

* Except in the last 2 experiments, change of body weight is taken to represent fluid exchange only. For reasons set forth in the text, it has been assumed that the water gain exceeds the weight gain by $0.26 \mathrm{kgm}$. in Experiment 9 and by 1 to $2 \mathrm{kgm}$. in Experiment 10.

recorded. Total water exchange calculated from the metabolism of base by Equation 2 is in satisfactory agreement in most cases with the observed weight changes. The most striking exceptions, noted in Experiment 7, will be discussed later. In the first period of Experiment 5, $\Delta \mathrm{W}$ calculated by Equation 2 agrees almost exactly with the loss of body weight; in the second period, however, the calculated exchange is only $0.39 \mathrm{kgm}$. while the weight increases $0.89 \mathrm{kgm}$. If the change of concentration of base in the water of serum is assumed to be $1 \mathrm{~m}$. Eq., instead of the observed $2 \mathrm{~m}$. Eq., the calculated $\Delta \mathrm{W}$ becomes $0.74 \mathrm{kgm}$., which agrees closely with the gain of weight. Since analytical error of $1 \mathrm{~m}$. Eq. is admitted, the results in this experiment require no further explanation, but serve to reemphasize the effect of slight changes of serum base upon the relationship between base and water balance. In most of the experiments calculation of $\Delta \mathrm{W}$ from base balances alone (Equation 3), without correction for changes in concentration of base in body water, gives results which are much inferior to those obtained by the use of Equation 2 in which this correction has been attempted. The most striking exception to this statement occurs in Experiment 9 in which the average concentration of base throughout the body fluids appears to have remained fairly constant despite the change in its concentration in serum water. A possible explanation will be offered in the discussion. In 2 instances, Experiment 4 and the second period of Experiment 6, there has been an actual storage of base which, when corrected for changes in concentration by Equation 2, yields strongly negative values for $\Delta \mathrm{W}$ which, are in fair agreement with the observed weight changes. Too much stress should not be placed upon the quantitative agreement between the calculated water exchange and observed body weight changes in the first 3 experiments since it will be recalled that the values for serum base are unreliable. These changes are, however, at least in the proper direction to support the validity of our concepts. Because the body weight changes can hardly be taken to represent $\Delta W$ in Experiment 10, a different method of analysis must be used. Under the conditions of this experiment (v. s.) the tissue wastage could hardly have been greater than $2 \mathrm{kgm}$. or less than $1 \mathrm{kgm}$. A body weight gain of $0.35 \mathrm{kgm}$. was noted. The water gain, then, must have been no more than $2.35 \mathrm{kgm}$., nor less than $1.35 \mathrm{kgm}$., which would require the retention of between $2.35 \times 140=330 \mathrm{~m}$. Eq. and $1.35 \times 140=189$ m. Eq. of $\mathrm{Na}+\mathrm{K}$. Actually $546 \mathrm{~m}$. Eq. were retained, leaving between 216 and $357 \mathrm{~m}$. Eq. to 
increase the concentration of base in approximately $47 \mathrm{kgm}$. of body water by between 4.6 and $7.6 \mathrm{~m}$. Eq. per liter. The observed increase of base in the water of the serum was $5 \mathrm{~m}$. Eq. per liter, thus supporting the contention that changes in the concentration of base in the water of the serum are reflected throughout the body water and that corrections for such changes must be made in calculating water exchange from base balances.

Calculations of extracellular fluid exchange $(\Delta \mathrm{E})$ from $\mathrm{Na}$ by Equation 4 or from $\mathrm{Cl}$ by Equation 5 show remarkably good agreement in most instances. The large discrepancies noted in Experiments 2 and 3 are not to be taken too seriously because of the known analytical errors in these experiments. In several of the experiments the changes in the concentration of $\mathrm{Na}$ and $\mathrm{Cl}$ in the serum exert very appreciable effects on the calculation of $\Delta \mathrm{E}$. For example, in the second period of Experiment 6, both $\mathrm{Na}$ and $\mathrm{Cl}$ balances were positive during a profuse diuresis. During the diuresis, however, the concentrations of these ions in the water of the serum increased more than could be accounted for by the amounts retained. Consequently the calculated values for $\Delta \mathrm{E}$ are both slightly negative. In the first period of Experiment 5 the observed losses of $\mathrm{Na}$ and $\mathrm{Cl}$ were not proportional to their concentrations in the body fluids. Yet the observed changes of concentrations of these electrolytes in the serum were of such magnitude and direction that the values for $\Delta \mathrm{E}$ calculated from both electrolytes are almost identical. In the first period of Experiment 8 , the $\mathrm{Cl}$ balance was positive while the $\mathrm{Na}$ balance was negative. The observed changes in concentration are such, however, that calculation of $\Delta \mathrm{E}$ from either $\mathrm{Na}$ or $\mathrm{Cl}$ indicates a slight increase in the volume of extracellular fluids.

\section{DISCUSSION}

That the proposed formula (Equation 2) for the calculation of the total water exchange of the body is fundamentally sound seems probable from the results of these experiments. In most of the experiments the values derived from this formula are in satisfactory agreement with the observed changes of body weight. The exchanges so calculated are generally far superior to those calculated from base balances alone (Equation 3 ).
This implies the essential correctness of the assumptions made in the derivation of Equation 2, namely, that changes of the concentration of base in the water of serum are equalized throughout the water of the body and that this water makes up approximately 70 per cent of the body weight. The first assumption is true, of course, only if osmotic equilibrium between the various portions of the body fluids is established at the times when periods are begun and ended. This was probably not true in Experiment 7 which may explain the poor results obtained by Equation 2 in this case.

In this experiment, the subject of which had diabetes insipidus, calculation of water exchanges gives absurdly high values. That the water of the body in this instance may have been considerably less than 70 per cent of the body weight is admitted. With the extreme changes of concentration noted in this experiment, the effect of error in this assumption on the calculations may be great. If instead of 70 per cent of the body weight, 50 per cent is used, however, the calculated exchanges will still be unreasonably high. It is possible to speculate upon the mode of production of osmotic gradients of the proper direction to reconcile the findings. The tremendous volumes and low salt concentrations of the urine of the diuretic periods are indicated in Table V. The excretion of such large amounts of water without appreciable amounts of salt should cause a rise in the concentration of base in the serum unless the water is constantly replenished by $a b-$ sorption from the gastro-intestinal tract. If fluid intake is now restricted so that alimentary absorption is eliminated, continued diuresis should result in a rise in the base of the serum so rapid that large gradients may be established between serum and tissues. Water was taken in large amounts during the diuretic periods of this experiment except for a few hours before the periods were terminated. Regardless of the changes of concentration of base noted for the periods as a whole, then, it seems reasonable to infer that at their conclusion a rapid increase in the concentration of base in the serum took place, in which event a gradient of $3 \mathrm{~m}$. Eq. between the water of serum and tissues is not improbable. Values for the base of body fluids as a whole, assuming the above gradients, are given in column 5 of Table V. Because the conditions at the start of 
TABLE V

Additional dato and calculations from Experiment 7

\begin{tabular}{|c|c|c|c|c|c|c|c|c|}
\hline \multirow{3}{*}{$\begin{array}{c}\text { Period } \\
\text { number }\end{array}$} & 1. & 2. & 3. & 4. & 5. & 6. & 7. & 8. \\
\hline & \multicolumn{3}{|c|}{ Urine } & \multicolumn{2}{|c|}{ Concentration of base in } & \multicolumn{2}{|c|}{$\begin{array}{l}\Delta \mathrm{W} \text { from Equation } 2 \\
\Delta \mathrm{B} \text { derived from column }\end{array}$} & \multirow{2}{*}{$\begin{array}{l}\text { Change of } \\
\text { weight of } \\
\text { body }\end{array}$} \\
\hline & Volume & $\mathrm{Na}$ & $\mathrm{Cl}$ & $\begin{array}{l}\mathrm{H}_{2} \mathrm{O} \text { of serum } \\
\text { (determined) }\end{array}$ & $\begin{array}{l}\mathrm{H}_{2} \mathrm{O} \text { of body } \\
\text { (assumed } \\
\text { average) }\end{array}$ & 4 & 5 & \\
\hline $\begin{array}{l}\text { I. . } \\
\text { II. . } \\
\text { III. . } \\
\text { IV... } \\
\text { V... }\end{array}$ & $\begin{array}{c}\text { liters per day } \\
5.15 \\
1.03 \\
5.39 \\
7.74 \\
1.57\end{array}$ & $\begin{array}{c}\text { m. Eq. per liter } \\
9 \\
41 \\
12 \\
17 \\
96\end{array}$ & \begin{tabular}{|c|} 
m. Eq. per liter \\
10 \\
43 \\
18 \\
19 \\
81
\end{tabular} & $\begin{array}{c}\text { m. Eq. } \\
163 \\
153 \\
143 \\
154 \\
157 \\
146\end{array}$ & $\begin{array}{c}m . E q . \\
150 \\
143 \\
151 \\
154 \\
146\end{array}$ & $\begin{array}{l}\text { kgm. } \\
+3.48 \\
+3.69 \\
+4.13 \\
-0.06 \\
+5.18\end{array}$ & $\begin{array}{l}\text { kgm. } \\
\\
+2.60 \\
-3.14 \\
-0.06 \\
+4.11\end{array}$ & $\begin{array}{l}\text { kgm. } \\
+1.08 \\
+1.76 \\
+2.15 \\
+0.10 \\
+3.19\end{array}$ \\
\hline
\end{tabular}

Period 1 are not definitely known, no attempt has been made to assume a gradient at that time. No water was taken during the whole night previous to the conclusion of the pituitrin periods and diuresis had not set in, so that no gradient need be assumed at these times. Total water exchanges recalculated by Equation 2, using instead of the observed values for base in the water of serum the assumed values for base in body water as a whole, are presented in Table V, column 7 . In each period the results so obtained approach more nearly the observed changes of weight. While this discussion is highly speculative it calls attention to the possibility of the existence of osmotic gradients within the body which may require consideration under certain conditions. The particular gradients assumed in this instance have no quantitative significance and are of directional significance only in so far as they rest on reasonable, though yet unproved, inferences concerning the physiological disturbance in diabetes insipidus. Experiments to demonstrate the actual nature of gradients under these conditions are contemplated. Attempts to locate the point of maximum gradient between the various body fluids must likewise be highly speculative. If tissue cells behave like red blood corpuscles, however, their adjustment to the immediately contiguous portions of the body fluids must be almost immediate. Likewise changes in the osmotic pressure of the serum must be transmitted very rapidly to the portions of the extracellular fluids immediately adjacent to the capillaries. Redistribution of base throughout the many ramifications of the extracellular fluids, however, can occur only through diffusion which is presumably a relatively slow process so that the major portion of the gradient probably lies in the extracellular fluids. To cite an extreme example, a large effusion which has contact with the capillaries only over the pleural surfaces would be expected to adjust itself completely to changes in serum concentration very slowly.

That the water exchange calculated by Equation 3 is superior to that calculated by Equation 2 in Experiment 9 has already been noted. There is a gain of about $3.75 \mathrm{kgm}$. of water, which in itself should require the retention of $3.75 \times 142$ $=532 \mathrm{~m}$. Eq. of $\mathrm{Na}+\mathrm{K}$. Actually only 518 m. Eq. were retained, leaving no excess to increase the concentration of base throughout the body fluids to the same extent as it was observed to increase in the water of the serum. That is, either the osmotic pressure of the serum was higher than that of the cells at the end of the experiment or the osmotic pressure of the cells was increased by something other than accession of base. The alternative in this instance may lie in a change in the reaction of the body fluids. At the start of the experiment the $\mathrm{CO}_{2}$ content of the serum was 86.9 volumes per cent as a result of previous depletion of $\mathrm{Cl}$ through vomiting. At the conclusion of the experiment this had returned to the normal level of 65.3 volumes per cent. The shift in reaction in an acid direction which presumably accompanied the fall of $\mathrm{CO}_{2}$ would cause the cells to swell if the osmotic pressure of the surrounding interstitial fluid remained constant. It is possible that the rise in osmotic 
pressure of this fluid indicated by the observed rise of serum base was equalled in the cells without change of concentration of base by a diminution of the amount of base bound to protein which because of its large base-combining power is relatively ineffective osmotically. Changes of this nature are known to occur in red blood corpuscles when the reaction of the blood is changed.

That the values for extracellular water exchange calculated by Equations 4 and 5 are in good agreement in most cases has been noted. This lends support to the assumptions made in the derivation of these equations, namely that $\mathrm{Na}$ and $\mathrm{Cl}$ are distributed similarly through a restricted portion of the body fluids, probably the extracellular portion, that changes of the average concentrations of these ions in these fluids parallel those in the water of serum, and that the extracellular fluids comprise something of the order of 20 per cent of the body weight.

The volume of water in the cells is determined not only by the $\mathrm{K}$ balance but also by the total concentration of base in their environment, the interstitial fluids. ${ }^{4}$ If the concentration of base does not change, intracellular water exchange and $\mathrm{K}$ balance should parallel one another; or if the amount of $K$ in the body remains constant, cell water must vary roughly in inverse proportion to the concentration of base in the water of serum; or if both the $\mathrm{K}$ content of the body and the base concentration in its water vary, each of these changes will affect the intracellular water content, and their effects may lie in the same or opposite directions. Thus in Experiment 8, in spite of the fact that $\mathrm{K}$ was retained during both periods, the changes of base concentration were such that a marked gain of cell water must have occurred during the first period and a marked loss during the second period. This leads to a consideration of the $\mathrm{K}$ exchanges of the body. Transfer of base across the membrane of the human red blood cell has never been demonstrated either in vitro or in vivo. It seems reasonable to believe that the

\footnotetext{
4 The distribution of water between cells and serum is presumably affected also by changes in the $\mathrm{pH}$ of the fluid media of the body. There is no knowledge of the quantitative aspects of this change. In only one of the present experiments, which has already been discussed, need this be considered, since in the others there were probably no significant changes of $\mathrm{pH}$.
}

red cell does not change its base content during its life in the circulation, in which case it must make its osmotic adjustments chiefly by changes in water content. As a consequence it is possible to cause hemolysis of these cells with ease in vitro by dilution of the blood with water or solutions of diffusible substances and with difficulty in vivo by extreme changes in osmotic pressure such as those occurring in severe water intoxication (40). The impermeability of other body cells must be facultative, however, as evidenced by changes in the $\mathrm{K}$ content of the body observed in balance studies. When marked storage or wastage of protein occurs, similar changes in $\mathrm{K}$ are usually noted. Large exchanges of $\mathrm{K}$ have been noted, however, in instances when the body is presumably in $\mathrm{N}$ equilibrium, for example the $\mathrm{K}$ loss noted in the diuresis produced by the administration of acidifying salts (41). Furthermore, $\mathrm{K}$ loss out of proportion to the loss of protein has been noted in diabetic acidosis (42). In both of these instances the excretion of $\mathrm{K}$ helps to combat excessive change in the reaction of the body by supplying base for the excretion of $a b-$ normal accumulations of acids. This loss of cellular base also serves to prevent excessive swelling of the tissue cells which might result from the change of reaction of the tissues and in the latter case, from decrease of concentrations of extracellular base as well. Such excessive swelling might be detrimental not only from the standpoint of cellular function but also because it would serve to deplete further the already diminished volume of extracellular fluids.

The $\frac{\text { potassium }}{\text { nitrogen }}$ ratio of the urine of Gamble's fasting children exceeded the same ratio in muscle water, as calculated from the analyses of Katz (4). Gamble assumed that, for each gram of protein metabolized, a definite fixed amount of cellular water together with its potassium was freed. Potassium excreted in excess of that estimated in this manner to result from the destruction of protoplasm he attributed to diminution of cell water. He suggested that this diminution might be the result of glycogen depletion. It has been shown above, however, that cellular water may vary over a wide range without any change of the nitrogen or glycogen or even of $\mathrm{K}$ balance as the result of a change in the osmolar 
concentration of the body water as a whole through the addition or removal of water without base or of a change in the concentration of sodium in interstitial fluids, which necessitates an exchange of water with the cells in order to restore osmotic equilibrium. The treatment accorded the data of these experiments presents compelling evidence in support of the objections previously raised (43) to the concept that cellular protein or glycogen is associated in such fixed proportion with water that the excretion of one inevitably entails the elimination of an equivalent amount of the other.

Changes in the calculated volume of extracellular and intracellular fluids may occur independently of one another and may even be in opposite directions. Thus, in the second period of Experiment 5 , when the salt stores of the body have been restored to a greater extent than the water stores of the body, as indicated by the observed increase in the concentration of base in body water, the calculated gain of extracellular fluid exceeds the total gain of water by the body. That is the volume of interstitial fluid has gained not only from exogenous sources but also at the expense of the cells, which have yielded water in the reestablishment of osmotic equilibrium. In Experiment 6, when pituitrin was withdrawn, in the second period, a profuse diuresis resulted during which 36 $\mathrm{m}$. Eq. of $\mathrm{Na}$ were retained and the concentration of sodium in the water of serum increased $8 \mathrm{~m}$. Eq. per liter. Calculation of water exchanges indicates that the entire diuresis has occurred at the expense of the cells, which, by yielding water, raise their osmotic pressure, without accession of $\mathrm{K}$, to the new level established in the serum. During the first period of Experiment 8 there was a gain of $1.60 \mathrm{kgm}$. in weight and a calculated gain of $1.83 \mathrm{kgm}$. of water without significant change in the $\mathrm{Na}$ and $\mathrm{Cl}$ balance of the body, and with a marked decrease in the concentrations of these ions in the serum. Calculation of $\Delta \mathrm{E}$ by Equations 4 and 5 yields values of 0.17 and 0.45 $\mathrm{kgm}$. respectively. That is, the major portion of the water gain occurred in the cells which, by swelling, had adjusted their osmotic pressure to the lowered level established in the interstitial fluids. In the second period, water balance was again positive but sufficient $\mathrm{Na}$ and $\mathrm{Cl}$ were retained to supply all the retained fluid, and in addition to increase the concentrations of these ions in the interstitial fluids. Apparently the base concentration in the cells was increased by the surrender of water to the interstitial fluids, the volume of which, therefore, increased from both exogenous and endogenous sources. The calculated values for $\Delta \mathrm{E}$ are 3.86 and $4.22 \mathrm{kgm}$. respectively by Equations 4 and 5 while $\Delta \mathrm{W}$ calculated from Equation 2 is only $2.60 \mathrm{kgm}$. and body weight gain was only $3.31 \mathrm{kgm}$.

Changes of the concentrations of serum proteins in the shorter experiments probably occurred only through changes of serum volume and can consequently serve as a measure of the latter. This is not true, of course, in conditions such as mercury poisoning, in which large amounts of protein may be lost from the circulation. The exchange between serum and the remainder of the interstitial fluids is not directly affected by electrolyte changes since the capillaries are freely permeable to electrolytes. Therefore changes in serum volume and the volume of interstitial fluids need not parallel one another. In Experiment 9 a large gain in extracellular fluid volume was accompanied by a proportional fall of serum protein. However, large gains of extracellular fluid volume occurred in the second periods of Experiments 5 and 8 without any significant changes of serum protein, and, therefore, presumably of serum volume. When pituitrin was given, the blood volume increased markedly in these experiments. In Experiment 6, the serum proteins fell from 8.50 to 7.50 per cent when pituitrin was given, indicating an increase of approximately 13 per cent in serum volume. During the same time the volume of extracellular fluids increased only $0.34 / 50=7$ per cent of the original volume. A much more striking disparity occurred in the second period of the same experiment when the serum volume fell markedly without any significant change in extracellular fluid volume as calculated from the metabolism of either $\mathrm{Na}$ or $\mathrm{Cl}$.

\section{SUMMARY AND CONCLUSIONS}

Formulae have been derived for the calculation of total water exchange and extracellular water exchange from changes in the electrolytes of the body. These formulae have been tested by application to experimental studies in man.

Exact quantitative accuracy is not claimed for 
the methods of calculation of water exchange presented in this paper. They serve, however, to throw some light upon the mechanisms of fluid exchange between the various compartments of the body fluids as well as between the body and the environment.

The results of the experiments, moreover, tend to confirm certain assumptions which have been made concerning the distribution of the bases and chloride in the body. These are:

1. That the concentration of total base throughout all of the water of the body is approximately alike and that change of the concentration in any portion of the water is equalled in all other portions.

2. That $\mathrm{Na}$ is almost entirely confined to the extracellular portions of the water of the human body and that the same is true of $\mathrm{Cl}$ with the exception of the small amount of $\mathrm{Cl}$ present in the red blood corpuscles.

3. That the total water of the human body comprises approximately 70 per cent, and the extracellular portion 20 per cent, of the body weight.

That extracellular and intracellular fluid volumes may vary independently of each other and of blood volume has been indicated.

It has been suggested that in certain exceptional conditions gradients of osmotic pressure may be set up between serum and tissues and that changes of reaction of the body may distort the normal relation of base to water in the cells and interstitial fluids.

\section{BIBLIOGRAPHY}

1. Newburgh, L. H., Johnston, M. W., and FalconLesses, M., Measurement of total water exchange. J. Clin. Invest., 1929-30, 8, 161.

2. Lavietes, P. H., The metabolic measurement of water exchange. J. Clin. Invest., 1935, 14, 57.

3. Gamble, J. L., Ross, G. S., and Tisdall, F. F., The metabolism of fixed base during fasting. J. Biol. Chem., 1923, 57, 633.

4. Katz, J., Die mineralischen Bestandtheile des Muskelfleisches. Arch. f. d. ges. Physiol., 1896, 63, 1.

5. Greene, C. H., Bollman, J. L., Keith, N. M., and Wakefield, E. G., The distribution of electrolytes between serum and transudates. J. Biol. Chem., 1931, 91, 203.

6. Hastings, A. B., Salvesen, H. A., Sendroy, J., Jr., and Van Slyke, D. D., Studies of gas and electrolyte equilibria in blood. IX. The distribution of electrolytes between transudates and serum. J. Gen. Physiol., 1927, 8, 701.
7. Loeb, R. F., Atchley, D. W., and Palmer, W. W., On the equilibrium condition between blood serum and serous cavity fluids. J. Gen. Physiol., 1922, 4, 591.

8. Gilligan, D. R., Volk, M. C., and Blumgart, H. L., Observations on the chemical and physical relation between blood serum and body fluids. I. The nature of edema fluids and evidence regarding the mechanism of edema formation. J. Clin. Invest., 1934, 13, 365.

9. Van Slyke, D. D., Wu, H., and McLean, F. C., Studies of gas and electrolyte equilibbria in the blood. V. Factors controlling the electrolyte and water distribution in the blood. J. Biol. Chem., 1923, 56, 765.

10. Eisenman, A. J., Unpublished studies.

11. Yannet, H., and Darrow, D. C., The chemical changes in red cells accompanying changes in the concentration of plasma. (To be published.)

12. Klinghoffer, K. A., The permeability of the red blood cell membrane to glucose. (To be published.)

13. Wakeman, A. M., Eisenman, A. J., and Peters, J. P., A study of human red blood cell permeability. J. Biol. Chem., 1927, 73, 567.

14. Eisenman, A. J., Lavietes, P. H., and Peters, J. P., Unpublished studies.

15. Peters, J. P., and Kydd, D. M., Unpublished studies.

16. Schechter, A. J., Electrolyte and volume changes in fluids injected into the peritoneal cavity. Yale J. Biol. and Med., 1931, 4, 167.

17. Schechter, A. J., Cary, M. K., Carpentieri, A. L., and Darrow, D. C., Changes in composition of fluids injected into the peritoneal cavity. Am. J. Dis. Child., 1933, 46, 1015.

18. Benedict, F. G., A study of prolonged fasting. Carnegie Institution of Washington, 1915, Publication No. 203.

19. Drake, T. G. H., McKhann, C. F., and Gamble, J. L., Total water and chloride content of dehydrated rats. J. Exper. Med., 1930, 51, 867.

20. Harrison, H. E., Darrow, D. C., and Yannet, H., Unpublished studies.

21. Hetherington, M., The state of water in mammalian tissues. J. Physiol., 1931, 73, 184.

22. Lavietes, P. H., Unpublished study.

23. Peters, J. P., The distribution and movement of water and solutes in the human body. Yale J. Biol. and Med., 1933, 5, 431.

24. Hastings, A. B., Edema. Yale J. Biol. and Med. (Proc. Clin. Congress Conn. State Med. Soc.), 1933, 6, 80.

25. Eggleton, M. G., Diffusion of inorganic phosphate into and out of the skeletal muscles and bones of the frog. J. Physiol., 1933, 79, 31.

26. Eggleton, M. G., and Eggleton, P., Carnosine in amphibian voluntary muscle. Quart. J. Exper. Physiol., 1933, 23, 391.

27. Crandall, L. A., and Anderson, M. X., Estimation of the state of hydration of the body by the amount of water available for the solution of sodium thio- 
cyanate. Am. J. Digestive Dis. and Nutrition, 1934, 1, 126.

28. Sherman, H. C., Chemistry of Food and Nutrition. Macmillan Co., New York, 1924, 2d ed., Appendix, Table II, p. 421.

29. Eisenman, A. J., A note on the Van Slyke method for the determination of chlorides in blood and tissue. J. Biol. Chem., 1929, 82, 411.

30. Barber, H. H., and Kolthoff, I. M., A specific reagent for the rapid gravimetric determination of sodium. J. Am. Chem. Soc., 1928, 50, 1625.

31. Shohl, A. T., and Bennett, H. B., A micro method for the determination of potassium as iodoplatinate. J. Biol. Chem., 1928, 78, 643.

32. Hald, P. M., The determination of the bases of serum and whole blood. J. Biol. Chem., 1933, 103, 471.

33. Peters, J. P., and Van Slyke, D. D., Quantitative Clinical Chemistry. II. Methods. Williams and Wilkins Co., Baltimore, 1932, p. 718.

34. Harvey, S. C., The quantitative determination of the chlorides in the urine. Arch. Int. Med., 1910, 6, 12.

35. Sunderman, F. W., and Williams, P., The analysis of chloride in tissues. J. Biol. Chem., 1933, 102, 279.
36. Moore, D. D., and Peters, J. P., Unpublished study. 37. Hancock, W., Whitehouse, A. G. R., and Haldane, J. S., The loss of water and salts through the skin and the corresponding physiological adjustments. Proc. Roy. Soc. London, s. B, 1929, 105, 43.

38. Viale, G., Absorption et élimination cutanée de l'eau et du chlorure sodique. Arch. ital. de biol., 1915, $63,321$.

39. Vasti, A., The insensible water loss through the skin. Am. J. Physiol., 1932, 102, 60.

40. Misawa, H., Uber das Wesen der sogenannten Wasserintoxikation. Japan. J. M. Sc., 1927 (Int. Med.), 1, 355.

41. Gamble, J. L., Blackfen, K. D., and Hamilton, B., A study of the diuretic action of acid producing salts. J. Clin. Invest., 1925, 1, 359.

42. Atchley, D. W., Loeb, R. F., Richards, D. W., Jr., Benedict, E. M., and Driscoll, M. E., On diabetic acidosis. A detailed study of electrolyte balances following the withdrawal and reestablishment of insulin therapy. J. Clin. Invest., 1933, 12, 297.

43. Peters, J. P., and Lavietes, P. H., The nature of "preformed water." J. Clin. Invest., 1933, 12, 695.

44. Eisenman, A. J., and Peters, J. P., Unpublished data. 